\title{
Cardiorespiratory Fitness and Components of the Metabolic Syndrome in Sedentary Men
}

\author{
Marie-Ėve Riou ${ }^{a, b}$ Étienne Pigeon ${ }^{a, b} \quad$ Josée St-Onge ${ }^{a, b} \quad$ Angelo Tremblay ${ }^{a, b}$ André Marette ${ }^{c, d}$ \\ S. John Weisnagel ${ }^{a, c, e}$ Denis R. Joanisse ${ }^{a, b}$ \\ a Division of Kinesiology, Laval University, \\ ${ }^{\mathrm{b}}$ Laval Hospital Research Center, \\ ${ }^{\mathrm{c}}$ Research Center on Lipidic Diseases, CHUL, \\ ${ }^{d}$ Department of Anatomy and Physiology, \\ e Diabetes Research Unit, CRCHUL, Laval University, Québec, OC, Canada
}

\section{Key Words}

Fitness - Sedentary men · Metabolic disease

\section{Summary}

Objective: To investigate the relationships between fitness and components of the metabolic syndrome in sedentary men. Subjects and Methods: 39 subjects (34-53 years) were evaluated for fitness $\left(\dot{\mathrm{V}}_{2 \max }\right)$ and anthropometric, metabolic, and skeletal muscle phenotypes. $\dot{\mathrm{V}}_{2 \max }$ was assessed on a bicycle ergometer whereas other variables were obtained from an oral glucose tolerance test (OGTT), hydrostatic weighing, and a muscle biopsy. Results: Pearson and partial correlations adjusted for fat mass (FM), waist circumference (WC), muscle enzyme activities (citrate synthase (CS), cytochrome c oxidase (COX)), and capillary density were used to investigate the independent relationships between variables. Negative correlations between $\dot{\mathrm{V}}_{2 \max }$ and WC as well as blood pressure and OGTT test were observed. When adjusted for FM, correlations remained between $\dot{\mathrm{V}}_{2 \max }$ and $\mathrm{WC}(\mathrm{r}=-0.46, \mathrm{p}<0.01)$ and systolic blood pressure $(r=-0.35, p<0.05)$. When adjusted for WC and CS activity, all correlations were lost except for high-sensitivity C-reactive protein (hs-CRP) ( $r=-0.34$, $\mathrm{p}<0.05$ ) which remained when adjusted for CS activity. Adjustment for COX activity failed to remove correlations with hs-CRP ( $r=-0.36, p<0.05)$, age $(r=0.34, p<0.05)$, WC $(r=-0.35, p<0.05)$, and blood pressure. Negative correlations persisted when fitness was adjusted for the mean number of capillaries. Conclusion: The effects of fitness on components of the metabolic syndrome in sedentary men are explained by abdominal obesity and muscle phenotypes.

\section{Introduction}

The metabolic syndrome is defined as a clustering of atherosclerotic risk factors simultaneously occurring in the same individual [1-3]. Major components of the metabolic syndrome include central obesity, abnormal glucose metabolism, dyslipidemia, and hypertension [1,3]. Regular physical activity has been recommended as an effective preventative approach to modulate the metabolic syndrome, the benefits of which are believed to occur in part from the improvement of physical fitness $[4,5]$. For example, Laaksonen et al. [6] showed that men who are less fit have a 7-fold greater chance of developing the metabolic syndrome compared to fit and physically active men. Also, higher levels of cardiorespiratory fitness were shown to be associated with a decreased risk of having the metabolic syndrome independently of the amount of visceral and subcutaneous fat, highlighting the potential benefits of increased fitness in the obese $[7,8]$.

However, fitness levels vary significantly between subjects, and this is true even when adjustments are made for physical activity. This phenomenon likely results from interindividual differences in the genetic background as well as from the cumulative effects of many small differences in everyday behavior. In sedentary subjects, it is not fully understood which impact a high level of cardiorespiratory fitness might have on components of the metabolic syndrome.

Accordingly, the aim of this study was to investigate if a higher level of cardiorespiratory fitness $\left(\dot{\mathrm{V}}_{2 \max }\right)$ in sedentary men could impact components of the metabolic syndrome. Also, we investigated if the impact of fitness could be explained by related anthropometric and/or skeletal muscle phenotypes that are known to influence oxygen consumption. We hypothesized that sedentary men with higher levels of fit-

\section{KARGER}

Fax +497614520714

Information@Karger.de

www.karger.com (c) 2009 S. Karger GmbH, Freiburg

Accessible online at:

www.karger.com/ofa 
ness would be protected against metabolic perturbations usually found in the metabolic syndrome and that this protection would occur independently of the level of obesity and of the oxidative potential of skeletal muscle.

\section{Subjects and Methods}

\section{Subjects}

A total of 39 sedentary men aged between 34 and 53 years participated in this cross-sectional study. Of these, 11 were normal weight controls $\left(\mathrm{BMI} \leq 25 \mathrm{~kg} / \mathrm{m}^{2}\right), 12$ were obese $\left(\mathrm{BMI}>30 \mathrm{~kg} / \mathrm{m}^{2}\right)$ with normal glucose tolerance, and 16 were obese with impaired glucose tolerance. Sedentary lifestyle was defined by the absence of participation in regular leisuretime or intense physical activity over the 3 previous months or longer. Specifically, this included activities involving an energy expenditure of 8 metabolic equivalents (METS) or more and activities lasting $30 \mathrm{~min}$ or more, for more than once a week [9]. All potential subjects underwent a medical examination, a medical history questionnaire, and a $75 \mathrm{~g}$ oral glucose tolerance test (OGTT) prior to inclusion. Individuals with diabetes (fasting plasma glucose concentration $>7.0 \mathrm{mmol} / \mathrm{l}$ and/or $2 \mathrm{~h}$ plasma glucose $\geq 11.1 \mathrm{mmol} / \mathrm{l}$ after bolus glucose ingestion), body weight fluctuation of $\pm 2 \mathrm{~kg}$ in the last 6 months, smokers, heavy alcohol consumers, asthmatics under steroid therapy, or those with liver, renal, or uncontrolled thyroid disorders were excluded. Subjects were also excluded if they were medicated with steroid hormones, alpha- or beta-blockers, diuretics, or other modulators of lipid metabolism (thiazolidinediones, statins, insulin). Those on calcium channel blockers, angiotensin-converting enzyme inhibitors, and angiotensin receptor antagonists were not excluded if they had been on stable doses in the last 3 months. Any history or physical findings of coronary heart disease, peripheral vascular disease, hypertension (diastolic blood pressure $>90 \mathrm{~mm} \mathrm{Hg}$, systolic blood pressure > $140 \mathrm{~mm} \mathrm{Hg}$ ), or intolerance to exercise resulted in exclusion of the participants. Physical activity levels were quantified with the ARIC/Baecke questionnaire [10], a modified version of the original Baecke questionnaire [11]. Tests were usually administered in the aforementioned order and over a 3- to 4-week period. The research protocol was approved by the Université Laval ethics committee, and all subjects provided written informed consent.

\section{Body Composition}

Body mass was measured to the nearest $0.1 \mathrm{~kg}$ using a calibrated scale including a tension gauge (Intertechnology Inc., Don Mills, ON, Canada) and a Digital Panel Indicator (Beckman industrial series 600; Beckmann Coulter Canada Inc., Mississauga, ON, Canada). Standing height was measured to the nearest millimeter using a wall stadiometer. Lean body mass and fat mass (FM) were evaluated by the hydrostatic weighing technique as previously described [9]. Waist circumference (WC) was measured in duplicate at the mid-distance between the iliac crest and last rib margin with a flexible steel metric tape to the nearest $0.1 \mathrm{~cm}$. Resting blood pressure was measured using a mercury manometer and is reported as the average of 4 measurements on the right arm of subjects sitting for $30 \mathrm{~min}$ or more.

\section{Oral Glucose Tolerance Test}

After an overnight fast, an OGTT with a $75 \mathrm{~g}$ glucose load was performed. Blood samples were collected through a venous catheter from an antecubital vein at $-15,0,30,60,90$, and 120 min following glucose ingestion for the determination of plasma glucose, C-peptide, and insulin concentrations [12]. Plasma glucose was measured enzymatically, whereas plasma insulin was measured by radioimmunoassay with polyethylene glycol separation [13, 14]. Subjects were classified as glucose-tolerant if fasting plasma glucose and $2 \mathrm{~h}$ post-bolus injection glucose levels were $<7.0$ and
$<7.8 \mathrm{mmol} / 1$, respectively. Subjects were glucose-intolerant if their plasma glucose level was $\geq 7.8 \mathrm{mmol} / 12 \mathrm{~h}$ following bolus ingestion.

\section{Cardiorespiratory Fitness $\left(\dot{V} O_{2 \max }\right)$}

Maximal oxygen consumption was measured using an incremental exercise test on a bicycle ergometer (Ergo-Metrics 800s; SensorMedics, Yorba Linda, CA, USA). Following a 5-min warm-up period between 50 and $75 \mathrm{~W}$, subjects were submitted to an incremental test starting between 100 and $150 \mathrm{~W}$, with an increase of $25 \mathrm{~W}$ every $2 \mathrm{~min}$. Direct measurements of $\mathrm{O}_{2}$ (Ametek S-3A with a Zircon cell) and $\mathrm{CO}_{2}$ (Anarad AR411 infrared gas analyzer) were taken every $30 \mathrm{~s}$. During the test, subjects were instructed to maintain at least 70 revolutions per min. The test was ended when participants could not maintain the required speed or upon the appearance of a usual indicator for the termination of exercise testing [15]. Blood pressure and perceived exertion (Borg analogue scale) were measured every $2 \mathrm{~min}[16]$.

\section{Plasma Lipid-Lipoprotein and C-Reactive Protein}

The plasma lipid-lipoprotein profile and C-reactive protein (as an indicator of systemic inflammation and risk for heart disease) were analyzed from blood samples collected from the antecubital vein into vacutainer tubes containing EDTA after an overnight fast. Cholesterol and triglyceride concentrations were determined enzymatically in plasma with a Technicon RA-500 analyzer (Bayer Corporation Inc., Tarrytown, NY, USA) and enzymatic reagents obtained from Randox (Randox Laboratories, Crumlin, UK) [17]. Plasma very low density lipoprotein (VLDL) (density $<1.006 \mathrm{~g} / \mathrm{ml}$ ) were isolated by ultracentrifugation [18]. The HDL fractions $\left(\mathrm{HDL}_{2}, \mathrm{HDL}_{3}\right)$ were obtained after precipitation of LDL in the infranatant (density $>1.006 \mathrm{~g} / \mathrm{ml}$ ) with heparin and $\mathrm{MnCl}_{2}$ [18]. Plasma apolipoprotein A-I (apo A-I) and apolipoprotein B (apoB) concentrations were measured by the rocket immuno-electrophoretic method of Laurell [19]. The lyophilized serum standards for apolipoprotein measurements were prepared in the core laboratory at the Lipid Research Center of Laval University Medical Center and calibrated with reference standards obtained from the Centers for Disease Control. Plasma high-sensitivity C-reactive protein (hs-CRP) levels were measured on plasma stored at $-80{ }^{\circ} \mathrm{C}$ using the Behring latex-enhanced high-sensitivity assay on a Behring BN-100 nephelometer (Behring Diagnostics, Westwood, MA, USA) and the calibrators ( $\mathrm{N}$ Rheumatology Standard SL) provided by the manufacturer.

\section{Muscle Biopsies and Analyses}

After a standardized evening meal (macronutrient content: $17 \%$ protein, $38 \%$ lipid, and $45 \%$ carbohydrate) followed by an overnight (12-14 h) fast, biopsy samples were taken from the middle region of the vastus lateralis ( $15 \mathrm{~cm}$ above the patella) and $2 \mathrm{~cm}$ away from the fascia by the use of the percutaneous needle biopsy technique as previously described by Evans et al. [20] and regularly used in our laboratory [21]. Spectrophotometric assays of the maximal enzyme activities of citrate synthase (CS; EC 4.1.3.7) and cytochrome c oxidase (COX; EC 1.9.3.1) and histochemical determination of fiber type distribution and capillary supply were performed as previously described $[22,23]$.

\section{Statistical Analyses}

Statistics were performed using JMP 5.0.1 software (SAS Institute, Cary, NC, USA). Comparison of variables between lean, normal glucose-tolerant and glucose-intolerant obese was done by analysis of variance (ANOVA). Tukey HSD post-hoc tests were used to test significant differences revealed by ANOVA. The impact of body weight and fat free mass (FFM) on maximal oxygen consumption was also assessed using ANCOVA. Pearson correlations were used to examine relationships between $\dot{\mathrm{V}}_{2 \max }$ and other variables. Partial correlation analyses (adjusted for FM, WC, COX, CS, and mean capillaries per fibers) were performed between $\dot{\mathrm{V}}_{2 \max }$ and variables relating to metabolic health. The normal- 
Table 1. Physical characteristics of the subjects

\begin{tabular}{|c|c|c|c|c|}
\hline Variable & Lean $(\mathrm{n}=11)$ & $\begin{array}{l}\text { Obese normal glucose- } \\
\text { tolerant }(\mathrm{n}=12)\end{array}$ & $\begin{array}{l}\text { Obese glucose- } \\
\text { intolerant }(n=16)\end{array}$ & $\begin{array}{l}\text { ANOVA } \\
\text { p value }\end{array}$ \\
\hline Age, years & $44 \pm 1$ & $45 \pm 2$ & $42 \pm 1$ & 0.26 \\
\hline Body mass, $\mathrm{kg}$ & $73.9 \pm 1.8^{\mathrm{a}}$ & $99.5 \pm 3.6^{\mathrm{b}}$ & $107.9 \pm 3.3^{\mathrm{b}}$ & $<0.0001$ \\
\hline $\mathrm{BMI}, \mathrm{kg} / \mathrm{m}^{2}$ & $23.9 \pm 0.5^{\mathrm{a}}$ & $31.8 \pm 1.0^{\mathrm{b}}$ & $35.1 \pm 1.0^{c}$ & $<0.0001$ \\
\hline Waist circumference, $\mathrm{cm}$ & $88.7 \pm 2.0^{\mathrm{a}}$ & $110.1 \pm 3.0^{\mathrm{b}}$ & $117.5 \pm 2.3^{\mathrm{b}}$ & $<0.0001$ \\
\hline FFM, $\mathrm{kg}$ & $59.1 \pm 1.5^{\mathrm{a}}$ & $67.8 \pm 1.5^{\mathrm{b}}$ & $73.9 \pm 1.9^{c}$ & $<0.0001$ \\
\hline $\mathrm{FM}, \mathrm{kg}$ & $14.7 \pm 0.9^{\mathrm{a}}$ & $31.8 \pm 2.6^{\mathrm{b}}$ & $34.0 \pm 2.4^{\mathrm{b}}$ & $<0.0001$ \\
\hline Body fat, \% & $19.9 \pm 1.0^{\mathrm{a}}$ & $31.4 \pm 1.5^{\mathrm{b}}$ & $31.1 \pm 1.5^{\mathrm{b}}$ & $<0.0001$ \\
\hline$\dot{\mathrm{V}} \mathrm{O}_{2 \max }, \mathrm{ml} / \mathrm{kg} / \mathrm{min}$ & $38.2 \pm 1.6^{\mathrm{a}}$ & $32.1 \pm 1.0^{\mathrm{b}}$ & $29.7 \pm 1.2^{\mathrm{b}}$ & 0.0002 \\
\hline$\dot{\mathrm{V}} \mathrm{O}_{2 \max }, \mathrm{ml} / \mathrm{kg} \mathrm{FFM} / \mathrm{min}$ & $47.8 \pm 1.8$ & $46.9 \pm 1.0$ & $43.1 \pm 1.3$ & 0.05 \\
\hline \multirow[t]{2}{*}{ ARIC/Baecke total activity index } & $8.52 \pm 0.57$ & $7.08 \pm 0.36$ & $7.36 \pm 0.34$ & 0.06 \\
\hline & Lean $(\mathrm{n}=10)$ & $\begin{array}{l}\text { Obese normal glucose- } \\
\text { tolerant }(\mathrm{n}=11)\end{array}$ & $\begin{array}{l}\text { Obese glucose- } \\
\text { intolerant }(n=13)\end{array}$ & \\
\hline Systolic blood pressure, $\mathrm{mm} \mathrm{Hg}$ & $115 \pm 2^{\mathrm{a}}$ & $120 \pm 2^{\mathrm{a}}$ & $130 \pm 2^{b}$ & $<0.0001$ \\
\hline Diastolic blood pressure, $\mathrm{mm} \mathrm{Hg}$ & $78 \pm 1^{\mathrm{a}}$ & $81 \pm 1^{\mathrm{a}}$ & $86 \pm 1^{\mathrm{b}}$ & 0.0002 \\
\hline
\end{tabular}

Values are means \pm SE. Values that share the same letter are not statistically different using the Tukey HSD post-hoc test. ity of the distribution of the data was assessed with the Shapiro-Wilk W test and, where appropriate, transformations were used to normalize the distribution of raw data or residuals prior to statistical analyses. Values are presented as means \pm standard error (SE) of untransformed data throughout the text. Differences with $\mathrm{p}$ values $<0.05$ were considered statistically significant.

\section{Results}

\section{Subject Characteristics, Cardiorespiratory Fitness, and Physical Activity}

The physical characteristics of the age-matched sedentary subjects are shown in table 1 . As expected, anthropometric characteristics were significantly different between the 2 obese groups and the lean subjects. Obese glucose-intolerant subjects were also characterized by higher (but subclinical) systolic and diastolic blood pressure.

Cardiorespiratory fitness $\left(\dot{\mathrm{VO}}_{2 \max }\right)$, when expressed relatively to total body mass (expressed in $\mathrm{ml} / \mathrm{kg} / \mathrm{min}$ ), was significantly higher in lean men when compared to those in both obese cohorts (table 1). However, when expressed relatively to FFM ( $\mathrm{ml} / \mathrm{kg} \mathrm{FFM} / \mathrm{min})$, in order to better demonstrate the actual $\mathrm{O}_{2}$ extraction capacity of lean tissue, the difference between groups was largely lost, albeit a tendency $(\mathrm{p}=0.05)$ for a smaller value in the obese groups remained. ANCOVA results, however, confirm that when adjusted for body mass or FFM, there are no differences between groups in maximal aerobic power ( $\mathrm{p}$ values of 0.51 and 0.12 for the group term, respectively). Thus, per unit of active tissue during exercise (muscle), no large functional difference at the level of $\mathrm{O}_{2}$ consumption was found between our obese and lean groups. In terms of total physical activity levels (work, leisure, and sport) of the cohorts, no significant difference was found between groups when assessed using the ARIC/Baecke total activity index.

Typical of obese men, higher (approximately 2-fold) triglyceride levels and lower HDL cholesterol concentrations (lesser by approximately $25 \%$ ) were observed in our 2 cohorts of obese subjects (table 2). No differences were observed in total and low density lipoprotein (LDL) cholesterol levels between groups. Also, hs-CRP levels were found to be significantly higher in our obese groups (table 2). Using American Heart Association guidelines, average hs-CRP levels in the lean group $(<1 \mathrm{mg} / \mathrm{l})$ were consistent with a low risk, whereas those of the obese cohorts $(>1.0$ and $<3.0 \mathrm{mg} / \mathrm{l})$ indicated an average risk of developing cardiovascular disease. Within our obese glucose-tolerant cohort, $27 \%$ ( 3 of 11) of the subjects were found to have levels $>3 \mathrm{mg} / \mathrm{l}$, indicating a high risk for cardiovascular disease. This increased to $40 \%$ (6 of 15) of the subjects in our obese glucose-intolerant group.

Consistent with our classification of subjects by glucose tolerance status following OGTT, fasting plasma glucose was not different between the 3 groups, but obese glucoseintolerant men had significantly greater fasting and $120 \mathrm{~min}$ plasma insulin (approximately 2-fold) and plasma C-peptide (approximately 2-fold) levels when compared to lean subjects (table 2). Obese subjects with normal glucose tolerance were found to have intermediate values of fasting and $120 \mathrm{~min}$ insulin and C-peptide.

The enzyme activity of COX in the vastus lateralis was similar between groups, whereas the activity of CS was found to be lower in obese groups, with the lowest values observed in obese glucose-intolerant subjects. Histochemical analyses revealed that the mean number of capillaries per fiber was similar in the 3 groups (table 2 ). 
Table 2. Metabolic and skeletal muscle (vastus lateralis) characteristics of the subjects

\begin{tabular}{|c|c|c|c|c|}
\hline Variable & Lean $(n=11)$ & $\begin{array}{l}\text { Obese normal glucose- } \\
\text { tolerant }(\mathrm{n}=11)\end{array}$ & $\begin{array}{l}\text { Obese glucose- } \\
\text { intolerant }(n=15)\end{array}$ & $\begin{array}{l}\text { ANOVA } \\
\text { p value }\end{array}$ \\
\hline \multicolumn{5}{|l|}{ Metabolic characteristics } \\
\hline Triglycerides, mmol/1 & $1.1 \pm 0.2^{\mathrm{a}}$ & $2.1 \pm 0.2^{\mathrm{b}}$ & $2.7 \pm 0.2^{b}$ & $<0.0001$ \\
\hline Total cholesterol, mmol/l & $4.7 \pm 0.2$ & $5.1 \pm 0.3$ & $5.3 \pm 0.2$ & 0.18 \\
\hline HDL cholesterol, mmol/l & $1.3 \pm 0.1^{\mathrm{a}}$ & $1.0 \pm 0.1^{\mathrm{b}}$ & $1.0 \pm 0.1^{\mathrm{b}}$ & 0.0004 \\
\hline LDL cholesterol, mmol/1 & $3.0 \pm 0.2$ & $3.2 \pm 0.2$ & $3.3 \pm 0.1$ & 0.55 \\
\hline \multirow[t]{2}{*}{ hs-CRP, mg/l } & $0.65 \pm 0.12^{\mathrm{a}}$ & $2.10 \pm 0.48^{\mathrm{a}, \mathrm{b}}$ & $2.70 \pm 0.56^{\mathrm{b}}$ & 0.013 \\
\hline & Lean $(n=10)$ & $\begin{array}{l}\text { Obese normal glucose- } \\
\text { tolerant }(n=12)\end{array}$ & $\begin{array}{l}\text { Obese glucose- } \\
\text { intolerant }(n=16)\end{array}$ & \\
\hline \multicolumn{5}{|l|}{ Glycemia, mmol/1 } \\
\hline Fasting & $5.5 \pm 0.2$ & $5.8 \pm 0.1$ & $5.9 \pm 0.1$ & 0.19 \\
\hline $120 \mathrm{~min}$ & $5.2 \pm 0.5^{\mathrm{a}}$ & $6.5 \pm 0.2^{b}$ & $9.1 \pm 0.2^{c}$ & $<0.0001$ \\
\hline \multicolumn{5}{|l|}{ Insulinemia, mmol/1 } \\
\hline Fasting & $75.6 \pm 9.7^{\mathrm{a}}$ & $105.6 \pm 15.8^{\mathrm{a}, \mathrm{b}}$ & $163.7 \pm 23.7^{b}$ & 0.003 \\
\hline $120 \mathrm{~min}$ & $526 \pm 93^{\mathrm{a}}$ & $724 \pm 129^{\mathrm{a}}$ & $1,277 \pm 177^{\mathrm{b}}$ & 0.002 \\
\hline \multicolumn{5}{|l|}{ C-peptide, $\mathrm{mmol} / \mathrm{l}$} \\
\hline Fasting & $743 \pm 68^{\mathrm{a}}$ & $1,061 \pm 86^{\mathrm{a}, \mathrm{b}}$ & $1,305 \pm 195^{\mathrm{b}}$ & 0.005 \\
\hline \multirow[t]{2}{*}{$120 \mathrm{~min}$} & $3,906 \pm 546^{\mathrm{a}}$ & $4,992 \pm 437^{\mathrm{a}, \mathrm{b}}$ & $6,690 \pm 658^{b}$ & 0.006 \\
\hline & Lean $(\mathrm{n}=11)$ & $\begin{array}{l}\text { Obese normal glucose- } \\
\text { tolerant }(\mathrm{n}=10)\end{array}$ & $\begin{array}{l}\text { Obese glucose- } \\
\text { intolerant }(n=14)\end{array}$ & \\
\hline \multicolumn{5}{|l|}{ Skeletal muscle characteristics } \\
\hline $\mathrm{CS}$ activity, $\mathrm{U} / \mathrm{g}$ & $6.2 \pm 0.8^{\mathrm{a}}$ & $4.5 \pm 0.3^{\mathrm{a}, \mathrm{b}}$ & $4.2 \pm 0.4^{b}$ & 0.04 \\
\hline COX activity, U/g & $4.9 \pm 0.5$ & $4.2 \pm 0.4$ & $4.2 \pm 0.5$ & 0.53 \\
\hline Mean number of capillaries/fiber & $3.6 \pm 0.2$ & $4.4 \pm 0.3$ & $4.0 \pm 0.2$ & 0.07 \\
\hline
\end{tabular}

Values are means \pm SE. Values that share the same letter are not statistically different using the Tukey HSD post-hoc test.

\section{Relationship of Anthropometric and Metabolic Variables with Cardiorespiratory Fitness}

WC and blood pressure (systolic and diastolic) were found to correlate negatively with fitness $\left(\dot{\mathrm{V}}_{2 \max }\right)$ (table 3$)$. Negative correlations were also observed between fitness and glucose, insulin, and C-peptide levels during the OGTT (table 4). Similar results were obtained with fasting blood total triglycerides $(\mathrm{r}=-0.32, \mathrm{p}<0.05)$, VLDL triglycerides $(\mathrm{r}=-0.34, \mathrm{p}<0.05)$ as well as levels of hs-CRP (table 4). No correlations were observed between cardiorespiratory fitness and other fasting blood lipid and lipoprotein levels (NEFA, total cholesterol and cholesterol subfractions, triglyceride VLDL, LDL, HDL, and HDL subfractions, apo A-I and apoB subfractions). Positive correlations between fitness and activities of CS ( $r=0.43$, $\mathrm{p}<0.01), \operatorname{COX}(\mathrm{r}=0.60, \mathrm{p}<0.001)$, and the mean number of capillaries per fiber $(\mathrm{r}=0.38, \mathrm{p}<0.05)$ were observed, however, no such relationship was found for the mean fiber area irrigated per capillary ( $\mu \mathrm{m}^{2} / \mathrm{cap}$ ) (data not shown). These data indicate that a higher level of fitness in sedentary men is correlated with some anthropometric, metabolic, and skeletal muscle aerobic metabolic potential characteristics.

As relationships were found between fitness and obesity and muscle aerobic metabolic potential, and since the latter are known to impact on metabolic health, we used partial cor- relations in an attempt to elucidate the independent contributions of fitness to markers of metabolic health. When adjusted for FM, most correlations of elements of the metabolic syndrome with fitness were lost. Only those with WC and systolic blood pressure remained. Remarkably, all correlations lost significance when data were adjusted for WC in the partial correlation analyses. Relative to muscle characteristics, all correlations between fitness and metabolic health except those with hs-CRP (table 4) were lost when $\dot{\mathrm{VO}}_{2 \max }$ was adjusted for citrate synthase activity. Following adjustment for cytochrome c oxidase activity, correlations remained between fitness and hs-CRP (table 4) as well as with age, WC, and systolic and diastolic blood pressure. Finally, when $\dot{\mathrm{VO}}_{2 \max }$ was adjusted for the mean number of capillaries per fiber, almost all correlations persisted except for those with age, the ARIC/ Baecke total activity index, fasting glycemia, fasting C-peptide, and hs-CRP (table 4).

\section{Discussion}

An active lifestyle clearly improves health outcomes. The American College of Sports Medicine recommends increasing the volume of aerobic physical activity to prevent the meta- 
Table 3. Correlation coefficients (r values) between cardiorespiratory fitness and characteristics of the subjects, $\dot{\mathrm{VO}}_{2 \max }(\mathrm{ml} / \mathrm{kg}$ $\mathrm{FFM} / \mathrm{min}$ )

\begin{tabular}{|c|c|c|c|c|c|c|}
\hline & \multirow{2}{*}{$\begin{array}{l}\text { Pearson } \\
\text { correlation }\end{array}$} & \multicolumn{5}{|c|}{ Partial correlation adjusted for } \\
\hline & & FM & WC & CS & $\mathrm{COX}$ & Mean cap \\
\hline Age, years $(n=39)$ & NS & NS & NS & NS & $0.34^{\mathrm{a}}$ & NS \\
\hline BMI, $\mathrm{kg} / \mathrm{m}^{2}(\mathrm{n}=39)$ & NS & NS & NS & NS & NS & $-0.45^{\mathrm{a}}$ \\
\hline $\mathrm{WC}(\mathrm{n}=39)$ & $-0.38^{\mathrm{a}}$ & $-0.46^{\mathrm{b}}$ & - & NS & $-0.35^{\mathrm{a}}$ & $-0.51^{\mathrm{a}}$ \\
\hline $\mathrm{FM}, \mathrm{kg}(\mathrm{n}=39)$ & NS & - & NS & NS & NS & $-0.38^{\mathrm{a}}$ \\
\hline$\% \mathrm{FM}(\mathrm{n}=39)$ & NS & NS & NS & NS & NS & $-0.40^{\mathrm{a}}$ \\
\hline ARIC/Baecke total activity index $(\mathrm{n}=39)$ & NS & NS & NS & NS & NS & NS \\
\hline Systolic blood pressure, $\mathrm{mm} \mathrm{Hg}(\mathrm{n}=34)$ & $-0.40^{\mathrm{a}}$ & $-0.35^{\mathrm{a}}$ & NS & NS & $-0.39^{\mathrm{a}}$ & $-0.43^{\mathrm{a}}$ \\
\hline Diastolic blood pressure, $\mathrm{mm} \mathrm{Hg}(\mathrm{n}=34)$ & $-0.36^{\mathrm{a}}$ & NS & NS & NS & $-0.40^{\mathrm{a}}$ & $-0.39^{\mathrm{a}}$ \\
\hline
\end{tabular}

$\mathrm{FM}=$ Fat mass $; \mathrm{WC}=$ waist circumference CS = citrate synthase activity COX = cytochrome c oxidase activity Mean cap = mean number of capillaries per fiber; NS = not significant.

${ }^{\mathrm{a}} \mathrm{p}<0.05$.

${ }^{\mathrm{b}} \mathrm{p}<0.01$.
Table 4. Correlation coefficients ( $\mathrm{r}$ values) between cardiorespiratory fitness and OGTT variables and circulating hs-CRP; $\dot{\mathrm{VO}}_{2 \max }(\mathrm{ml} / \mathrm{kg}$ $\mathrm{FFM} / \mathrm{min}) ; \mathrm{n}=39$

\begin{tabular}{|c|c|c|c|c|c|c|}
\hline & \multirow{2}{*}{$\begin{array}{l}\text { Pearson } \\
\text { correlation }\end{array}$} & \multicolumn{5}{|c|}{ Partial correlation adjusted for } \\
\hline & & FM & WC & CS & $\mathrm{COX}$ & Mean Cap \\
\hline \multicolumn{7}{|c|}{ Glycemia, mmol/l } \\
\hline Fasting & NS & NS & NS & NS & NS & NS \\
\hline $120 \mathrm{~min}$ & $-0.34^{\mathrm{a}}$ & NS & NS & NS & NS & $-0.39^{\mathrm{a}}$ \\
\hline \multicolumn{7}{|c|}{ Insulinemia, mmol/l } \\
\hline Fasting & $-0.32^{\mathrm{a}}$ & NS & NS & NS & NS & $-0.36^{\mathrm{a}}$ \\
\hline $120 \mathrm{~min}$ & $-0.38^{\mathrm{a}}$ & NS & NS & NS & NS & $-0.36^{\mathrm{a}}$ \\
\hline \multicolumn{7}{|c|}{ C-peptide, mmol/l } \\
\hline Fasting & NS & NS & NS & NS & NS & NS \\
\hline $120 \mathrm{~min}$ & $-0.32^{\mathrm{a}}$ & NS & NS & NS & NS & $-0.36^{\mathrm{a}}$ \\
\hline hs-CRP, mg/l & $-0.40^{\mathrm{a}}$ & NS & NS & $-0.34^{\mathrm{a}}$ & $-0.36^{\mathrm{a}}$ & $-0.52^{\mathrm{b}}$ \\
\hline
\end{tabular}

$\mathrm{FM}=$ Fat mass; $\mathrm{WC}=$ waist circumference $\mathrm{CS}=$ citrate synthase activity COX = cytochrome $\mathrm{c}$ oxidase activity; Mean cap $=$ mean number of capillaries per fiber; $\mathrm{NS}=$ not significant. ${ }^{\mathrm{a}} \mathrm{p}<0.05$.

${ }^{\mathrm{b}} \mathrm{p}<0.01$. bolic syndrome based on epidemiological, prospective, and randomized control trial studies that have shown reduced cardiovascular disease, type 2 diabetes, and metabolic risk factors with this type of training [5, 6, 24-28]. Increasing muscle mass through resistance training could also positively affect insulin resistance and fatty acid metabolism as well as decrease FM $[29,30]$, further enforcing the message that physical activity in general is beneficial to counter metabolic dysfunctions.

Although the benefits of increased physical activity in preventing or treating these conditions are clear, the impact of greater cardiorespiratory fitness without regular physical activity is not. Studies have established that sedentary individuals or those with a low cardiorespiratory fitness are more susceptible to suffer from or develop the metabolic syndrome $[6,31]$, but how fitness relates to components of the metabolic syndrome remains unclear. The purpose of this study was to investigate if cardiorespiratory fitness in sedentary men was associated with elements of the metabolic syndrome.

Our simple correlation data suggest that a higher level of fitness in sedentary men matched for overall levels of physical activity potentially protects against obesity, hypertension, a deteriorated blood lipid-lipoprotein profile, and inflammation. This would seem to indicate that those sedentary individuals who benefit from an elevated cardiorespiratory fitness might be protected from metabolic dysfunction.

However, the relationships between fitness, obesity, and skeletal muscle characteristics observed in our study introduce a potentially important confounding effect [32]. We chose to study the contributions of fitness beyond those of obesity and skeletal muscle phenotypes by using partial correlation analyses. When adjusted for FM, most correlations between fitness and markers of metabolic health were lost, with the exception 
of systolic blood pressure. This would suggest that high fitness can protect against hypertension in sedentary men with varying levels of obesity. Even more dramatic, however, were the effects of adjusting for abdominal obesity, where all relationships between fitness and elements of the metabolic syndrome and health were lost. This suggests that no matter the fitness level of a sedentary subject, the effects of increased abdominal obesity will always prevail over metabolic health. Our results also showed that, when adjusted for the potential for oxidative metabolism of muscle, almost all relations between fitness and the markers of metabolic health were lost except for that with the inflammatory marker hs-CRP. This suggests that the oxidative potential of muscle also has a more important effect on these markers of metabolic health than fitness. Moreover, these relations suggest that inflammation could be attenuated by better fitness independently of muscle oxidative potential.

The negative relationship between cardiorespiratory fitness and abdominal obesity could be indicative of a causal link. Evidence of a significant impact of obesity on the machinery solicited during fitness testing is found in the literature. For instance, a number of studies have shown skeletal muscle perturbations in obesity, changes typically observed in the machinery relating to energy metabolism. Notably, muscle from obese individuals displays reduced oxidative enzyme activities and reduced electron transport chain activity $[33,34]$. At least some of these changes can occur following weight gain, as revealed in an overfeeding study [35]. Our results that show a tendency for a decreased $\dot{\mathrm{VO}}_{2 \max }$, when expressed per $\mathrm{kg}$ of FFM in obese men, could derive at least in part from such changes to skeletal muscle metabolic potential.

The present study has some limitations. Our findings are limited to a population of relatively healthy sedentary men and need to be confirmed in a larger cohort of subjects that should include women and younger individuals. Our small sample size could have limited our ability to discern minor contributions of fitness to metabolic health, although we are confident we can rule out major effects. Also, if these results apply to a population of severely metabolically deteriorated individuals, such as those suffering from type 2 diabetes, remains to be demonstrated. Finally, it also remains to be shown how fitness impacts on other metabolic aspects related to obesity and diabetes, such as insulin resistance.

The results from this study should not be used to diminish the well-established importance of regular physical activity in the struggle against metabolic disease. Instead, they should be considered as cautionary and be used to stress the need for regular physical activity even in those individuals who are found to have high fitness levels with little or no training. Physical activity has been demonstrated to impact on abdominal obesity as well as the aerobic metabolism potential of skeletal muscle, and in light of our results, this might be of particular importance for those men who suffer from a deteriorated metabolic profile.

\section{Acknowledgements}

The authors would like to thank Guy Fournier, Jean Doré, Marc Brunet, Linda Drolet, Nancy Parent, Marie Tremblay, Rollande Couture, ValérieÈve Julien, Rachelle Duchesne, and Ginette Lapierre for expert technical assistance. Special thanks to all participants for their precious collaboration. This work was supported by a CIHR research grant to DRJ. M-È. Riou was supported by a Diabète Québec scholarship.

\section{Disclosure}

All authors who participated in this study have no conflict of interest to declare.

\section{References}

1 Daskalopoulou SS, Mikhailidis DP, Elisaf M: Prevention and treatment of the metabolic syndrome. Angiology 2004;55:589-612.

2 LaMonte MJ, Barlow CE, Jurca R, Kampert JB, Church TS, Blair SN: Cardiorespiratory fitness is inversely associated with the incidence of metabolic syndrome: a prospective study of men and women Circulation 2005;112:505-512.

3 Eckel RH, Grundy SM, Zimmet PZ: The metabolic syndrome. Lancet 2005;365:1415-1428.

4 Lakka TA, Laaksonen DE, Lakka HM, Mannikko N, Niskanen LK, Rauramaa R, Salonen JT: Sedentary lifestyle, poor cardiorespiratory fitness, and the metabolic syndrome. Med Sci Sports Exerc 2003;35:1279-1286.

$\checkmark 5$ Ross R, Freeman JA, Janssen I: Exercise alone is an effective strategy for reducing obesity and related comorbidities. Exerc Sport Sci Rev 2000;28:165-170.

6 Laaksonen DE, Lakka HM, Salonen JT, Niskanen LK, Rauramaa R, Lakka TA: Low levels of leisuretime physical activity and cardiorespiratory fitness predict development of the metabolic syndrome. Diabetes Care 2002;25:1612-1618.
7 Lee S, Kuk JL, Katzmarzyk PT, Blair SN, Church TS, Ross R: Cardiorespiratory fitness attenuates metabolic risk independent of abdominal subcutaneous and visceral fat in men. Diabetes Care 2005; 28:895-901.

8 Blair SN, Kohl HW 3rd, Barlow CE, Paffenbarger RS Jr, Gibbons LW, Macera CA: Changes in physical fitness and all-cause mortality. A prospective study of healthy and unhealthy men. JAMA 1995; 273:1093-1098.

$\checkmark 9$ Bouchard C, Leon AS, Rao DC, Skinner JS, Wilmore JH, Gagnon J: The heritage family study. Aims, design, and measurement protocol. Med Sci Sports Exerc 1995;27:721-729.

10 Folsom AR, Arnett DK, Hutchinson RG, Liao F, Clegg LX, Cooper LS: Physical activity and incidence of coronary heart disease in middle-aged women and men. Med Sci Sports Exerc 1997;29: 901-909.

11 Baecke JA, Burema J, Frijters JE: A short questionnaire for the measurement of habitual physical activity in epidemiological studies. Am J Clin Nutr 1982;36:936-942.
12 Piche ME, Weisnagel SJ, Corneau L, Nadeau A, Bergeron J, Lemieux S: Contribution of abdominal visceral obesity and insulin resistance to the cardiovascular risk profile of postmenopausal women. Diabetes 2005;54:770-777.

13 Kvist H, Sjöström L, Tylén U: Adipose tissue volume determinations in women by computed tomography: technical considerations. Int J Obes 1986; 10:53-67.

14 Desbuquois B, Aurbach GD: Use of polyethylene glycol to separate free and antibody-bound peptide hormones in radioimmunoassays. J Clin Endocrinol Metab 1971;33:732-738.

15 Fletcher GF, Balady GJ, Amsterdam EA, Chaitman B, Eckel R, Fleg J, Froelicher VF, Leon AS, Pina IL, Rodney R, Simons-Morton DA, Williams MA, Bazzarre T: Exercise standards for testing and training: a statement for healthcare professionals from the American Heart Association. Circulation 2001;104:1694-1740.

16 Borg GA: Psychophysical bases of perceived exertion. Med Sci Sports Exerc 1982;14:377-381. 
17 Couillard C, Després JP, Lamarche B, Bergeron J, Gagnon J, Leon AS, Rao DC, Skinner JS, Wilmore $\mathrm{JH}$, Bouchard C: Effects of endurance exercise training on plasma HDL cholesterol levels depend on levels of triglycerides: evidence from men of the Health, Risk Factors, Exercise Training and Genetics (HERITAGE) Family Study. Arterioscler Thromb Vasc Biol 2001;21:1226-1232.

-18 Pascot A, Després JP, Lemieux I, Bergeron J, Nadeau A, Prud'homme D, Tremblay A, Lemieux S: Contribution of visceral obesity to the deterioration of the metabolic risk profile in men with impaired glucose tolerance. Diabetologia 2000;43: 1126-1135.

19 Avogaro P, Bon GB, Cazzolato G, Quinci GB: Are apolipoproteins better discriminators than lipids for atherosclerosis? Lancet 1979;1:901-903.

20 Evans WJ, Phinney SD, Young VR: Suction applied to a muscle biopsy maximizes sample size Med Sci Sports Exerc 1982;14:101-102.

21 Simoneau JA, Bouchard C: Human variation in skeletal muscle fiber-type proportion and enzyme activities. Am J Physiol 1989;257:E567-572.

22 Simoneau JA, Lortie G, Boulay MR, Thibault MC, Bouchard C: Repeatability of fibre type and enzyme activity measurements in human skeletal muscle. Clin Physiol 1986;6:347-356.

23 Rico-Sanz J, Rankinen T, Joanisse DR, Leon AS, Skinner JS, Wilmore JH, Rao DC, Bouchard C Familial resemblance for muscle phenotypes in the heritage family study. Med Sci Sports Exerc 2003; 35:1360-1366.
24 Thompson PD, Buchner D, Pina IL, Balady GJ, Williams MA, Marcus BH, Berra K, Blair SN, Costa F, Franklin B, Fletcher GF, Gordon NF, Pate RR, Rodriguez BL, Yancey AK, Wenger NK: Exercise and physical activity in the prevention and treatment of atherosclerotic cardiovascular disease: a statement from the Council on Clinical Cardiology (Subcommittee on Exercise, Rehabilitation, and Prevention) and the Council on Nutrition, Physical Activity, and Metabolism (Subcommittee on Physical Activity). Circulation 2003;107:3109-3116.

25 Laaksonen DE, Lindström J, Lakka TA, Eriksson JG, Niskanen L, Wikstrom K, Aunola S, KeinänenKiukaanniemi S, Laakso M, Valle TT, Ilanne-Parikka P, Louheranta A, Hämäläinen $\mathrm{H}$, Rastas $\mathrm{M}$, Salminen V, Cepaitis Z, Hakumäki M, Kaikkonen H, Härkönen P, Sundvall J, Tuomilehto J, Uusitupa M: Physical activity in the prevention of type 2 diabetes: the Finnish diabetes prevention study. Diabetes 2005;54:158-165.

$26 \mathrm{Hu}$ G, Sarti C, Jousilahti P, Silventoinen K, Barengo NC, Tuomilehto J: Leisure time, occupational, and commuting physical activity and the risk of stroke. Stroke 2005;36:1994-1999.

$27 \mathrm{Hu}$ G, Qiao Q, Silventoinen K, Eriksson JG, Jousilahti P, Lindström J, Valle TT, Nissinen A, Tuomilehto J: Occupational, commuting, and leisure-time physical activity in relation to risk for type 2 diabetes in middle-aged Finnish men and women. Diabetologia 2003;46:322-329.
8 Lakka TA, Laaksonen DE: Physical activity in prevention and treatment of the metabolic syndrome. Appl Physiol Nutr Metab 2007;32:76-88.

29 Banz WJ, Maher MA, Thompson WG, Bassett DR, Moore W, Ashraf M, Keefer DJ, Zemel MB Effects of resistance versus aerobic training on coronary artery disease risk factors. Exp Biol Med (Maywood) 2003;228:434-440.

30 Kelley DE: Skeletal muscle fat oxidation: timing and flexibility are everything. J Clin Invest 2005;115:1699-1702.

31 Brien SE, Katzmarzyk PT: Physical activity and the metabolic syndrome in Canada. Appl Physiol Nutr Metab 2006;31:40-47.

32 Riou M, Pigeon E, St-Onge J, Tremblay A, Marette A, Weisnagel SJ, Joanisse DR: Predictors of cardiovascular fitness in sedentary men. Appl Physiol Nutr Metab 2008;34:99-106.

33 Kelley DE, He J, Menshikova EV, Ritov VB: Dysfunction of mitochondria in human skeletal muscle in type 2 diabetes. Diabetes 2002;51:2944-2950.

34 Ritov VB, Menshikova EV, He J, Ferrell RE, Goodpaster BH, Kelley DE: Deficiency of subsarcolemmal mitochondria in obesity and type 2 diabetes. Diabetes 2005;54:8-14.

35 Sun G, Ukkola O, Rankinen T, Joanisse DR, Bouchard C: Skeletal muscle characteristics predict body fat gain in response to overfeeding in neverobese young men. Metabolism 2002;51:451-456. 